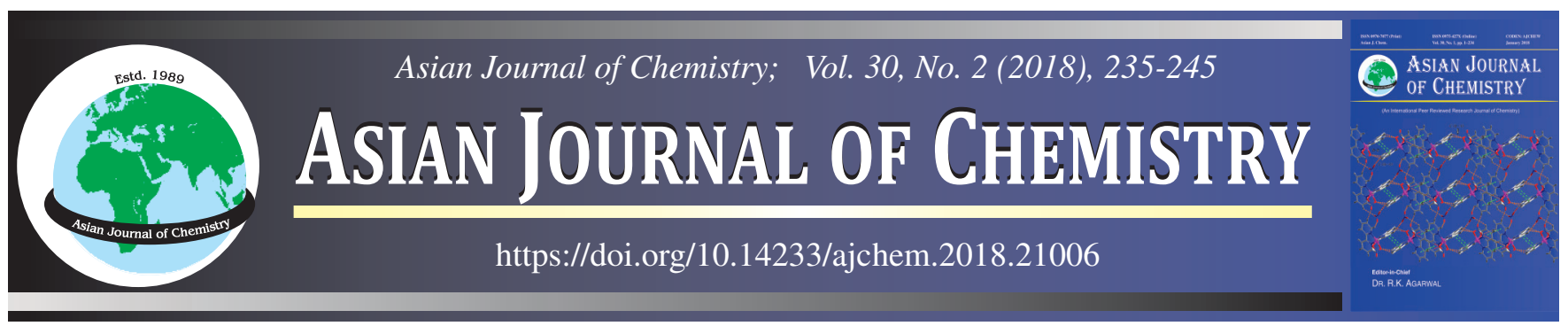

REVIEW

\title{
Domestic Use of Cooking Fuel in India: A Review on Emission Characteristics and Associated Health Concerns
}

Madhuri Verma ${ }^{1}$, Shamsh Pervez ${ }^{1, *}$, Manas Kanti Deb $^{1}$ and Dipanjali Majumdar ${ }^{2}$

${ }^{1}$ School of Studies in Chemistry, Pt. Ravishankar Shukla University, Raipur-492 010, India

${ }^{2}$ CSIR-National Environmental Engineering Research Institute, Kolkata Zonal Laboratory, i-8, Sector C, EKDP, E. M. Bypass, Kolkata-700 107, India

*Corresponding author: E-mail: shamshpervez@gmail.com; shamshp@yahoo.co.in

Received: 28 August 2017;

Accepted: 31 October 2017;

Published online: 31 December 2017;

AJC-18683

\begin{abstract}
One out of every three Indians use biomass fuels such as wood, animal dung and coal cake, crop residues as their primary domestic energy source. About 23 and $61 \%$ of urban and rural Indian households, respectively, rely on traditional stoves (Chullah) for cooking practices Household air pollution contains solid fuel burning emissions prominently, is reported to claim 4.3 million premature deaths yearly in developing countries. But most of the review studies to address air pollution scenario in India are focused on outdoor environments; major reason to review the current knowledge on emission estimates from household biomass burning and associated impacts on indoor air and human health. This review intends to critically discuss the variability associated with emission estimates and impacts of household air quality in different parts of India as presented in several research works, published during 2001-2015. About 27 and $11 \%$ increase in $\mathrm{PM}_{2.5}$ and $\mathrm{PM}_{10}$, respectively has been observed in Indian house-indoors during the assessment period. Emission factors, emission budgets of aerosol fractions, carbonaceous matter and other chemical components for household biofuel burning emissions were also summarized for the period of 2001-2015. Health effects studies due to household air pollution in India were also summarized and discussed. Improvement in ventilation system and modification in the pattern of fuels may contribute to reduce the effect of the pollution on national health. As there are no specific regulations or acts for controlling of household air pollution in India, urgent need is felt for implementing the strategies to create public awareness.
\end{abstract}

Keywords: Household air pollution, Biomass burning, Emission factor, Indoor air pollution, Health effect.

ᄂ - - - - - - - - - - - - - - - - - - - - - - - - - - -

\section{INTRODUCTION}

The population explosion along with prevalent industrialization coupled with urbanization results dense urban and rural centers with deteriorating air quality in developing countries. In developing countries around half of the world's population and up to $90 \%$ of rural household countries still rely on unprocessed biomass fuel (including fuel wood, dung cake and crop residues) burnt indoors in open fires using poorly implemented traditional stoves [1]. People, who spends on an average more than $14 \mathrm{~h}$ indoors, are reported to expose to high level of indoor air pollution not only due to proximity to the emissions resulting from burning of solid biomass fuels for cooking practices but also from infiltration of profuse outdoor pollution at places among other sources [2,3]. The major sources of indoor air pollution, globally, include infiltration of outdoor air, combustion of solid fuels, furnishings and constructions materials, ventilation systems [4]. These sources vary considerably between developing and developed country. Although $40 \%$ of poor ventilated Indian houses with the use of solid fuels for cooking practices are major hotspots of producing adverse health effects among dwellers, most of the reported Indian air quality (IAQ) studies were focused to address ambient-outdoor air pollution [5-7]. The status of household air pollution can reproduce the high level of harmful pollutants [7] consequently, among various sources of household air pollution, the environmental significance of cooking activities has drawn a great deal of attention. Cooking-related to household air pollution is known to be affected by the combustion of various fuels, cooking styles and efficiency of cooking stoves [9]. Many types of pollutants viz., particulate matter, carbonaceous matter (elemental carbon, polycyclic aromatic hydrocarbons and other organic compounds) are found to be released, mainly, from combustion of biomass [10].

Incomplete combustion of biomass can also serve as a route to transfer high levels of indoor pollutants to the exposed 
population especially those who are directly involved in cooking. Exposure to household air pollution may be responsible for approximately 4.3 million deaths in global scale [11] and $4 \%$ of the global burden of disease [12] and over 0.6 million premature deaths per year due to use of biomass fuels has been reported in year 2002 [13]. Exposure to particulate matter (PM), especially fine particulate matter, is associated with a wide range of diseases including allergic disorder (asthma, bronchitis) and respiratory infection [14]. Children and elderly population are particularly susceptible $[6,15]$. Smoke from biomass combustion shows huge risk factor for people and especially for females in developing countries [16]. Particulate matter has the influence over global climate and it was also suggested that the Asian Brown Cloud was partly formed due to cook stove emission [17]. A comprehensive review of findings reported in earlier published research studies on Indian air quality, solid fuel use and associated adverse health effects is felt necessary at this point to evaluate temporal variation in mass and chemical components of household indoor particulate matter, impact of different fuel use for cooking practices on indoor aerosols, variability associated to emission factors of aerosols and carbonaceous matter for different solid fuel use for cooking practices across the India to lay path for future studies and as well as legislations.

Exclusive review of the previous studies, the literature and the etiquette helped in revealing that rural and urban households depend upon various energy sources. Most of the families of that area are using unprocessed biomass as fuel like dung cakes (DC), fuel wood (FW), agricultural or crop residue (AR or CR), etc. Some people also use kerosene stoves and gas burners. About $23 \%$ and $61 \%$ of urban and rural Indian households, respectively, are relied on traditional stoves (chullah) for cooking practices according to the Census India, 2011. This review intends to present the variability associated with emission estimates and impacts on household air quality in different parts of India

Methodology: We tried to summarize the data and findings of a number of research publications from 2001 to 2015 on household air pollution in different regions of India [9,15,18-24]. We also intend to address the emission estimates of aerosols and carbonaceous matter during burning of solid fuels in cooking practices, associated Indian air quality and health effects in spatiotemporal scale.

India and domestic air pollution: Most of the studies on household air pollution have been conducted in India with major objectives to 1) determine gaseous and particulate pollutants in different types of indoor, 2) determine particulate and carbonaceous pollutants across various type of fuel burning during cooking practices, 3 ) to assess associated health effects among subjects encountered to respective indoors. Based on different objectives of reported studies on Indian air quality, the outcomes have been reviewed in four major sections: (a) Evaluation of spatiotemporal trend in mass concentration and associated chemical component of indoor aerosols in different Indian cities; (b) Evaluation of variability in emission estimates of size resolved aerosol fractions and associated carbonaceous matter during household fuel burning practices in different parts of India and (c) Assessment of reported health risks and adverse health effects due to household air pollution in different parts of India viz., Indo-Gangetic plain (IGP), Central peninsula plateau (CPP) and coastal plain (CP).

Most of the reported studies (about $>70 \%$ ) are conducted in Indo-Gangetic plain and many of the reviewed studies focused on different objective viz., quantification of indoor aerosols, measurements of selected organic and inorganic components and evaluation of emission factors of carbonaceous matter using different approaches from real-world situation to controlled chamber studies. Region-specific Indian average indoor $\mathrm{PM}_{2.5}$ plots in timescale of 2001-2015 is presented annually due to few reported studies on indoor aerosols in Central peninsula plateau and coastal plain regions.

Spatiotemporal variation in mass and chemical components of size resolved indoor aerosols in India: Few studies on measurement and characterization of indoor aerosols have been reported for Indian sub-continent conduct in India. Household indoor $\mathrm{PM}_{2.5}$ and $\mathrm{PM}_{10}$ measurements, conducted in different parts of India during last 15 years (2001-2015), were summarized (Fig. 1) to address associated spatiotemporal variation pattern. All reported studies (Table-1) have shown higher $\mathrm{PM}_{2.5}$ and $\mathrm{PM}_{-10}$ compared to National Ambient Air Quality Standards (NAAQS) by a factor of $>3$. The percentage changes (increase or decrease) in mass during the assessment period (2001-2015) is evaluated using trend line, plotted in the associated graph of temporal variation (Fig. 1). The mass values (Y-axis), corresponding to right-end of trend line was subtracted from those corresponding to left-end of trend line on 2001. The difference value was divided by mass value corresponding to left-end of trend line and resultant was multiplied by hundred to determine the percentage of increase or decrease throughout the assessment period. It has been evaluated that average indoor $\mathrm{PM}_{2.5}$ is raised $27 \%$ since from 2001, whereas $\mathrm{PM}_{10}$ has shown $11 \%$ increment during the assessment period. Unprocessed solid fuel combustion for cooking practices, poor ventilation properties associated to house structures and profuse outdoor infiltration are reported to be the major factors of higher increment in $\mathrm{PM}_{2.5}$ compared to $\mathrm{PM}_{10}[6,15,18,21]$. Few studies demonstrate the variability pattern of indoor particulate matter mass concentration in seasonal scale $[23,44]$.

During first five years of last fifteen years of $21^{\text {st }}$ century, most of the Indian air quality studies are limited to address only mass concentration of $\mathrm{PM}_{10}, \mathrm{PM}_{2.5}$ and respirable particulate

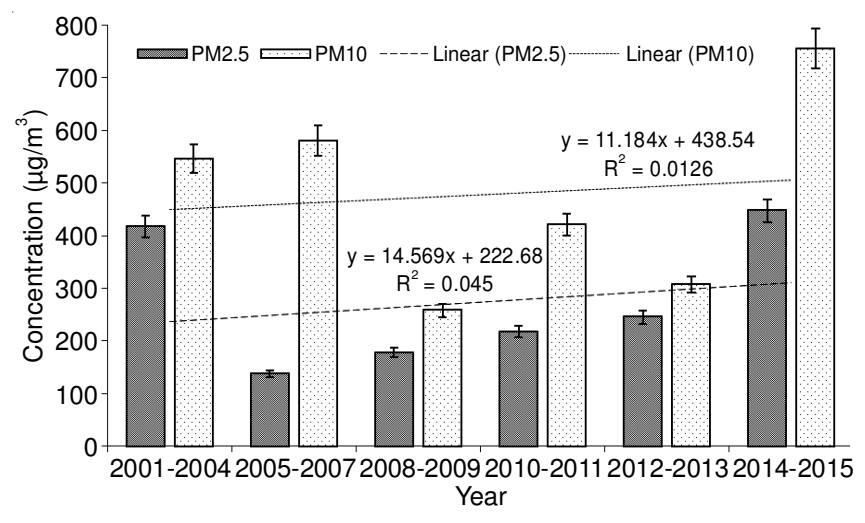

Fig. 1. Spatiotemporal variation in indoor mass concentration $\left(\mathrm{PM}_{10}\right.$ and $\mathrm{PM}_{2.5}$ ) in different cities of India 


\begin{tabular}{|c|c|c|c|c|c|}
\hline \multicolumn{6}{|c|}{$\begin{array}{l}\text { TABLE-1 } \\
\text { SPATIOTEMPORAL VARIATION IN MASS CONCENTRATION OF AEROSOL IN INDIA SINCE } 21^{\text {st }} \text { CENTURY }\end{array}$} \\
\hline \multirow{2}{*}{ Year measured } & \multirow{2}{*}{ Geographical plates } & \multirow{2}{*}{ Area } & \multicolumn{2}{|c|}{ Average mass concentration } & \multirow{2}{*}{ Ref. } \\
\hline & & & $\mathrm{PM}_{2.5}\left(\mu \mathrm{g} / \mathrm{m}^{3}\right)$ & $\mathrm{PM}_{10}\left(\mu \mathrm{g} / \mathrm{m}^{3}\right)$ & \\
\hline 2002 & Coastal plain & Tamil Nadu & - & 231 & [15] \\
\hline 2003 & Indo-Gangetic plain & Delhi & - & 1204 & [18] \\
\hline \multirow{5}{*}{2004} & Coastal plain & Tamil Nadu & 475 & - & [21] \\
\hline & Indo-Gangetic plain & West Bengal & 750 & - & [21] \\
\hline & & Uttaranchal & 1250 & - & [21] \\
\hline & Central peninsula plateau & Andhra Pradesh & - & 405 & [6] \\
\hline & & Madhya Pradesh & 875 & - & [21] \\
\hline \multirow[t]{3}{*}{2005} & Central peninsula plateau & Bhilai & - & 579.84 & [25] \\
\hline & & Madhya Pradesh & 825 & & [26] \\
\hline & & Maharastra & 635 & & [26] \\
\hline \multirow[t]{2}{*}{2007} & Indo-Gangetic plain & Agra & 202.95 & - & [27] \\
\hline & Central peninsula plateau & Andhra Pradesh & - & 1250 & [28] \\
\hline \multirow[t]{5}{*}{2008} & Indo-Gangetic plain & Agra & 202.95 & - & [27] \\
\hline & & Delhi & - & 138.5 & [29] \\
\hline & & West Bengal & 304 & 625 & [30] \\
\hline & & Patiala & 195 & - & [31] \\
\hline & Central peninsula plateau & Ahmedabad & 85 & - & [31] \\
\hline \multirow[t]{5}{*}{2009} & Indo-Gangetic plain & Uttar Pradesh & 175.5 & - & [27] \\
\hline & & Delhi & - & 410.6 & {$[32]$} \\
\hline & & Agra & 178 & 154.2 & [33] \\
\hline & & Patiala & 200 & - & [31] \\
\hline & Central peninsula plateau & Bhilai & - & 207.3 & [34] \\
\hline \multirow[t]{2}{*}{2010} & Coastal plain & Tamilnadu & 160 & 133.33 & [35] \\
\hline & Indo-Gangetic plain & Lucknow & 178 & - & [36] \\
\hline \multirow[t]{5}{*}{2011} & Indo-Gangetic plain & Kanpur & - & 481.2 & [37] \\
\hline & & Uttar Pradesh & 585.33 & 1275 & [38] \\
\hline & & Delhi & - & 381.31 & [39] \\
\hline & & Agra & 73 & 190.75 & [40] \\
\hline & & Punjab & 246 & - & [31] \\
\hline \multirow[t]{6}{*}{2012} & Indo-Gangetic plain & Haryana & 468 & - & [41] \\
\hline & & Agra & 126.83 & 210.75 & [27] \\
\hline & & Agra & 349.8 & - & [24] \\
\hline & Central peninsula plateau & Bhilai & - & 829.6 & [42] \\
\hline & & Pune & 140.5 & 212.6 & [43] \\
\hline & Coastal plain & Chennai & 54.49 & 172.97 & [44] \\
\hline \multirow[t]{4}{*}{2013} & Indo-Gangetic plain & Agra & 121.82 & 238.43 & [45] \\
\hline & & Delhi & 59.75 & 309.2 & [4] \\
\hline & Central peninsula plateau & Andhra Pradesh & 609 & - & [21] \\
\hline & & Pune & 141.76 & 243.815 & {$[46]$} \\
\hline \multirow[t]{3}{*}{2014} & Indo-Gangetic plain & Uttar Pradesh & 1218 & 2993 & [47] \\
\hline & & Agra & 121.82 & 238.43 & [45] \\
\hline & & Bhilai & 49.296 & 604.89 & [23] \\
\hline
\end{tabular}

matter (RPM) in households involved with cooking practices [15,18,21]. Balakrishnan et al. [15] have reported the indoor $\mathrm{PM}_{10}(\mathrm{RPM})$ in large samples (436) of rural households involved with cooking practices using biomass in Tamil Nadu and quantified exposures to respirable particulate matter (RPM) with value of $90 \pm 21 \mu \mathrm{g} \mathrm{m}{ }^{-3}$ for those subjects who were not involved with cooking, whereas $231 \pm 109 \mu \mathrm{g} \mathrm{m}^{-3}$ level has been determined for subjects involved with cooking activities. Similarly, Saksena et al. [18] predicted indoor respirable particulate matter (with average value $1204 \mu \mathrm{g} \mathrm{m}^{-3}$ ) in slum households involved with cooking activities using kerosene and biomass using micro environmental modeling. Balakrishnan et al. [6] quantified indoor respirable particulate matter with average concentration ranged from 73-732 $\mu \mathrm{g} \mathrm{m}^{-3}$ in gas versus solid fuel using households respectively and estimated the concentrations were significantly correlated with type of kitchen and fuel quantity with the ranged of average value from $80-573$ $\mu \mathrm{g} \mathrm{m}^{-3}$ in 412 rural homes in three districts of Andhra Pradesh. Pervez et al. [25] investigated the indoor concentration have been 2-3 times higher than outdoor particulate matter concentration in welding workshops. Balakrishnan et al. [21] measured in year 2004-2005, average concentration of $\mathrm{PM}_{2.5}$ ranged from $163 \mu \mathrm{g} \mathrm{m}^{-3}$ and $609 \mu \mathrm{g} \mathrm{m}^{-3}$ during cooking practices with use of solid fuel and living area, respectively.

The reported studies during next five years (2006-2010) have focused on chemical characterization of indoor fine particulates and associated indoor/outdoor relationships along with mass measurements. Different chemical species like ions, elements and carbonaceous species including volatile organic compounds (VOCs), polycyclic aromatic hydrocarbons (PAHs) are measured in several studies $[23,33,43]$. Goyal and Khare [32] studied indoor-outdoor levels of RSPM ( $\mathrm{PM}_{10}, \mathrm{PM}_{2.5}$, 
$\mathrm{PM}_{1.0}$ ) in a ventilated classroom of school buildings located near roadway traffic in Delhi city during August 2006 to August 2007. They estimated that if indoor-outdoor ratio (I/O) for all sizes of particulate matter is $>1$ which indicate that dwellers envelop does not protect from outside pollution as well as higher I/O for $\mathrm{PM}_{10}$ indicating the presence of indoor sources of pollution levels. Kulshrestha et al. [33] estimated the mean concentrations in urban, rural and roadside sites of Agra at indoor and outdoor environments during 2007-2008 and the average level of $\mathrm{PM}_{2.5}$ in indoors and outdoors were 178 and $195 \mu \mathrm{g} \mathrm{m}^{-3}$. Out of that mass water soluble elements contributed an average of $70 \%$ (29\% anions and $43 \%$ cations) in $\mathrm{PM}_{2.5}$. This study revealed that the trends of particulate matter mass concentration were roadside $>$ urban $>$ rural for outdoor and rural $>$ roadside $>$ urban for indoor. Massey et al. [27] have reported the measurements of indoor $\mathrm{PM}_{2.5}$ in selected households in Agra and recorded maximum average concentration of $\mathrm{PM}_{2.5}$ in rural homes $\left(173.03 \mu \mathrm{g} \mathrm{m}^{-3}\right)$, compared to road side homes $\left(137.93 \mu \mathrm{g} \mathrm{m}^{-3}\right)$ and urban homes $\left(135.55 \mu \mathrm{g} \mathrm{m}^{-3}\right)$ with significant contribution from outdoor infiltration. Balakrishna et al. [48] investigated the indoor and outdoor sources of arsenic in urban area of central India. Road traffic has shown higher contribution in indoor and automobile exhaust had shown higher contribution of arsenic. Masih et al. [49] studied PAHs concentration in particulate and gas phase was investigated in indoor and outdoor air during winter and summer season of urban residential and road side homes in semiarid region of India. In indoor roadside homes and urban residents, the annual mean concentration of particulate PAHs (PPAHs) were 5.53$952.28 \mathrm{ng} \mathrm{m}^{-3}$ and $4.10-826.73 \mathrm{ng} \mathrm{m}^{-3}$ respectively as well as outdoor PPAHs were 15.47- $1036.79 \mathrm{ng} \mathrm{m}^{-3}$ and 8.32-826.73 $\mathrm{ng} \mathrm{m}^{-3}$, respectively for both site. Whereas in common outdoor sources of PAHs were petrol and diesel combusted fuel and for indoor sources were cooking, smoking and incense burning are generator sets. During the last five years' block (20102015) of period of 2001-2015, most of indoor air quality studies included source apportionment, pollutants emission factor's development and evaluation of associated health risks. Review of emission factor values and health risks of pollutants associated to indoor aerosols have been described in succeeding sections. Impact of different household fuel use on relative source contribution estimates (SCEs) for house-indoor respirable particulate matter $\left(\mathrm{PM}_{5.0}\right)$ have been investigated in Raipur, India [42]. This study has evaluated that households with solid fuel combustion (dung cakes) contributed more than $45 \%$ to indoor respirable particulate matter, whereas household LPG stove emissions contributed up to $28 \%$ to indoor respirable particulate matter. Singh et al. [24] estimated the relationship between income groups and pollution level of the houses in Agra during July-2012. They categorized the income group into low, middle and high and the mean concentration of indoor $\mathrm{PM}_{2.5}$ were $46.7 \mu \mathrm{g} \mathrm{m}^{-3} 39.2 \mu \mathrm{g} \mathrm{m}^{-3}$ and $25.6 \mu \mathrm{g} \mathrm{m}^{-3}$, respectively with significant use of domestic energy in their houses. Goyal and Kumar [4] examined I/O of $\mathrm{PM}_{10}$ and $\mathrm{PM}_{2.5}$ in naturally (canteen, kitchen, reception) and mechanically ventilated buildings in Delhi. Irrespective of particulate matter types, the average I/O was $<1$ for mechanically ventilated buildings as compared with $>1$ for naturally ventilated micro environments with infiltration of outdoor air. Kulshrestha et al. [45] studied source characterization of trace metals in indoor environments at rural, urban and roadside homes of Agra. It revealed that the total contribution of trace metals is found to be 6.2 and $2.2 \%$ in $\mathrm{PM}_{2.5}$ and $\mathrm{PM}_{10}$, respectively. About 33-39 \% contribution of emissions from house indoors including cooking activities to toxic metals associated to indoor aerosols has been reported for rural and urban households. Roy et al. [46] conducted study at both urban and rural sites of Pune city, India. The study depicts the average mass concentration of $\mathrm{PM}_{10}$ and $\mathrm{PM}_{2.5}$ for both sites (mass concentration of $\mathrm{PM}_{10}$ for urban and rural site with a mean value of $176 \pm 57 \mu \mathrm{g} \mathrm{m}^{-3}$ and $283 \pm 185 \mu \mathrm{g}$ $\mathrm{m}^{-3}$, respectively as well as mean value of $\mathrm{PM}_{2.5}$ for both site were $105 \pm 61 \mu \mathrm{g} \mathrm{m}^{-3}$ and $176 \pm 126 \mu \mathrm{g} \mathrm{m}^{-3}$ respectively), which is multifold higher than NAAQS $\left(40 \mu \mathrm{g} \mathrm{m}^{-3}\right.$ for $\mathrm{PM}_{2.5}$ and 60 $\mu \mathrm{g} \mathrm{m}^{-3}$ for $\mathrm{PM}_{10}$ ). The authors attributed the possible reasons for high concentration of particulate matter found to be biofuel use in cooking and improper ventilation for rural site as well as infiltration of outdoor air for urban site. Authors also reported the average metals concentration trend in $\mathrm{PM}_{10}$ as $\mathrm{Fe}>\mathrm{Zn}>$ $\mathrm{Cu}>\mathrm{Ni}>\mathrm{Pb}>\mathrm{Cr}>\mathrm{Co}>\mathrm{Mn}>\mathrm{Cd}$ and $\mathrm{Fe}>\mathrm{Zn}>\mathrm{Ni}>\mathrm{Mn}>$ $\mathrm{Co}>\mathrm{Cr}>\mathrm{Cu}>\mathrm{Pb}>\mathrm{Cd}$ for rural and urban site, respectively.

Impacts of emissions from household fuel combustion on indoor air quality: Several air pollutants like gaseous pollutants $\left(\mathrm{CO}_{2}, \mathrm{CO}, \mathrm{NO}_{\mathrm{x}}, \mathrm{SO}_{\mathrm{x}}\right)$ particulates and carbonaceous matter (organic carbon, elemental carbon and PAHs) have been recognized to be associated with adverse health effects in rural and urban area of developed countries [50,51]. However, most of the studies concentrate on particulate matter as the most important class of air pollutants. Unprocessed biomass fuels produce $>100$ times respirable particulate matter than the modern fuels because of their low thermal, combustion and heat transfer efficiencies [52]. Several studies aimed to address the impact of emissions from different fuel combustions on indoor $\mathrm{PM}_{2.5}$ and $\mathrm{PM}_{10}$ during 2001-2015 and their result is summarized in Table-2 and Fig. 2. In an average, more than 150 and $300 \%$ higher averaged indoor $\mathrm{PM}_{10}$ was observed in household involved with solid fuel combustion, compared to those involved with kerosene and LPG usage, respectively. Similarly, more than 90 and nearly $150 \%$ higher averaged indoor $\mathrm{PM}_{2.5}$ was found in households involved with solid fuel use, compared to those involved with kerosene and LPG usage, respectively. About two-fold raise in averaged indoor $\mathrm{PM}_{10}$ compared to averaged indoor $\mathrm{PM}_{2.5}$ in households with solid fuels from those involved with kerosene and LPG has been found most likely due to incomplete combustion associated to solid fuel combustion. Therefore, earlier comparative study of various fuels clearly revealed that LPG contributes less amount of pollutants than biomass fuel $[21,24,37,38,58]$.

Singh and Jamal [55] discussed the indoor concentration of suspended particulate matter (SPM) during cooking times in various type of kitchen (including ventilated and less ventilated kitchen) using different type of fuels viz., biomass including fuel wood and dung cakes, LPG and showed that biomass emit large amounts of suspended particulate matter. Balakrishnan et al. [6] discussed a comparative study on concentration of particulate matter (aerodynamic diameter $\leq$ $\mathrm{PM}_{10}$ ) across various fuels. They also contributed that biomass 


\begin{tabular}{|c|c|c|c|c|c|c|c|}
\hline \multirow{3}{*}{ Year } & \multicolumn{7}{|c|}{$\begin{array}{c}\text { TABLE-2 } \\
\text { COMPARISON OF DIFFERENT FUELS MASS CONCENTRATION IN MICROGRAM PER CUBIC METER }\left(\mu \mathrm{g} / \mathrm{m}^{3}\right)\end{array}$} \\
\hline & \multicolumn{2}{|c|}{ Biomass (wood + dung cake) } & \multicolumn{2}{|c|}{ Kerosene } & \multicolumn{2}{|c|}{ LPG } & \multirow{2}{*}{ Ref. } \\
\hline & $\mathrm{PM}_{10}\left(\mu \mathrm{g} / \mathrm{m}^{3}\right)$ & $\mathrm{PM}_{2.5}\left(\mu \mathrm{g} / \mathrm{m}^{3}\right)$ & $\mathrm{PM}_{10}\left(\mu \mathrm{g} / \mathrm{m}^{3}\right)$ & $\mathrm{PM}_{2.5}\left(\mu \mathrm{g} / \mathrm{m}^{3}\right)$ & $\mathrm{PM}_{10}\left(\mu \mathrm{g} / \mathrm{m}^{3}\right)$ & $\mathrm{PM}_{2.5}\left(\mu \mathrm{g} / \mathrm{m}^{3}\right)$ & \\
\hline 2001 & 1210 & 520 & - & - & 140 & 45 & [53] \\
\hline \multirow[t]{2}{*}{2003} & 322 & 188.77 & - & - & 130 & 70.96 & [54] \\
\hline & 604 & 358.35 & - & - & 138 & 157.68 & \\
\hline \multirow[t]{2}{*}{2004} & 340 & - & 156 & - & 61 & - & [6] \\
\hline & 470 & - & - & - & & & \\
\hline 2008 & 625 & 304 & - & - & 169 & 89.00 & [30] \\
\hline 2010 & 317.59 & 178.78 & - & - & 117.82 & 60.55 & [55] \\
\hline \multirow[t]{2}{*}{2011} & - & 481.2 & - & - & - & 135.60 & [37] \\
\hline & - & 972 & - & - & - & 148.00 & [56] \\
\hline 2012 & - & 349.8 & - & - & - & 145.10 & [24] \\
\hline \multirow[t]{4}{*}{2013} & - & 590 & - & 254 & - & 179 & [21] \\
\hline & - & 741 & - & - & - & - & \\
\hline & - & 157 & - & - & - & - & [45] \\
\hline & - & 190 & - & 198 & - & 135.6 & \\
\hline \multirow[t]{3}{*}{2014} & 2993 & 1218 & 491 & 416 & 341 & 122 & [47] \\
\hline & & 156 & - & 108 & - & 14 & [57] \\
\hline & & 144 & - & - & - & - & \\
\hline
\end{tabular}

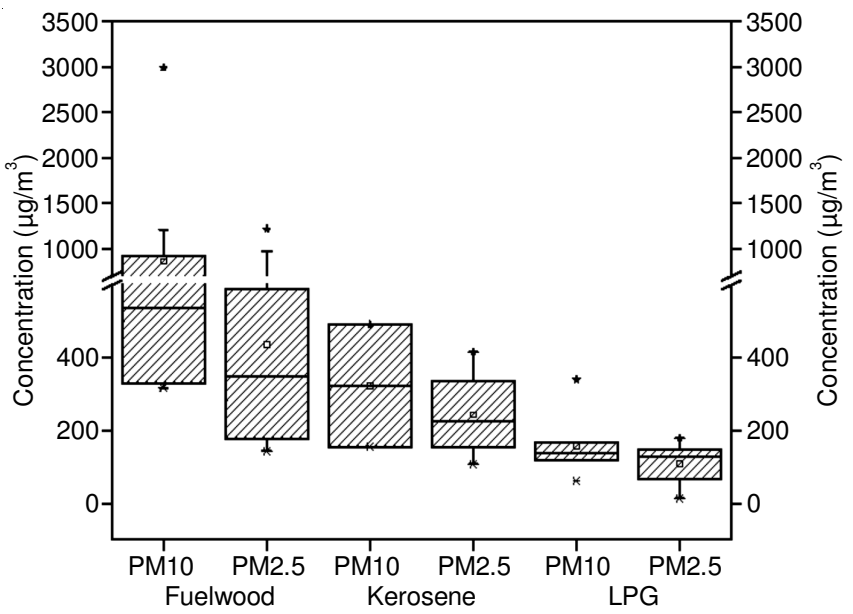

Fig. 2. Comparison of different types of fuels and its effects of particulate matter size distribution

using kitchen had 4-5 times higher $\mathrm{PM}_{10}$ than LPG using kitchen and as well as 2-3 times more $\mathrm{PM}_{10}$ than kerosene using kitchen. Lahiri and Chowdhury [30] have conducted in their study in West Bengal compared and found that women using biomass as fuel were more exposed to smoke than LPG users. The concentration of $\mathrm{PM}_{10}$ in LPG and biomass using kitchen during cooking times were reported to be $169 \pm 22 \mu \mathrm{g} \mathrm{m}^{-3}$ and $625 \pm$ $127 \mu \mathrm{g} \mathrm{m}^{-3}$, corresponding $\mathrm{PM}_{2.5}$ level were $89 \pm 12 \mu \mathrm{g} \mathrm{m}^{-3}$ and $304 \pm 77 \mu \mathrm{g} \mathrm{m}^{-3}$, respectively.

Emissions and emission factors of pollutants: Biomass fuels are at the high end of pollution emissions and at the low end of combustion efficiency across modern and traditional fuels [59]. Traditional cooking practices with using of biomass, convert $6-20 \%$ of the fuel carbon to toxic substances. The burning of biomass fuels actual cooking is only $18 \%$, whereas $74 \%$ of the carbon is decadent as waste heat [15]. Smoke particles are composed of about $60 \%$ organic carbon (OC) and 5-10\% elemental carbon (EC) or black carbon (BC) [60]. Black carbon also called soot particles (SP). Soot particles are extremely absorbing type of aerosols [61] and can play an important role in global warming. Biomass burning (BB) is the second largest emission inventories of trace gases and primary fine carbonaceous particles in worldwide. Recent biomass burning studies have furnished new emission factors measurements. Emission information is representing mainly emissions ratio (ER) or emission factors. emission factors are expressed as grams of pollutant emitted per gram of dry fuel burned $(\mathrm{g} / \mathrm{kg})$ [62]. In terms of human impacts, emission factors is directly associated with the exposure of the pollutant to humans and scope of areas covered by pollutant emissions. This is applicable for all pollutants associated to biomass burning including non-methane organic compounds (NMOC), which also affect secondary organic aerosol (SOA) and ozone formation [63]. A number of studies to address emission factors of associated air pollutants for household solid fuel combustions have been conducted in different parts of India and summarized in Table-3. Comparison of average reported emission factors of selected air pollutants $\left(\mathrm{PM}_{2.5}, \mathrm{OC}, \mathrm{EC}\right.$ and PAHs) for different solid biofuel combustion have been presented in Table-3 and Fig. 3. Combustion of dung cakes have shown two- and three-fold higher emission factors of $\mathrm{PM}_{2.5}$ compared to combustion of fuel wood and crop residue, respectively. Contrast to $\mathrm{PM}_{2.5}$ emission factors, organic carbon has shown two-fold higher emission factors for combustion of dung cakes and crop residue, compared to fuel wood. Interestingly, emission factors of elemental carbon for combustion of crop residue are found to be two-fold higher than those related to combustion of fuel wood and dung cakes. This might be due to comparatively higher incomplete combustion associated to dung cakes and fuel wood than crop residue. As far as reported PAHs emission factors is concern, fuel wood combustion has shown two- and nine-fold higher values compared to crop residue and dung cakes, respectively.

Ritual based biomass burnings are also common practice in India and Dewangan et al. [23] reported the associated emission factors of elemental carbon to compare with another domestic biomass burning [74]. Emission factors values for elemental carbon for ritual based biomass burning were reported to be six to ten-fold higher than crop residue $(0.75 \mathrm{~g} / \mathrm{kg})$, two 
TABLE-3

EMISSION FACTORS OF POLLUTANTS

\begin{tabular}{|c|c|c|c|c|c|c|c|c|c|}
\hline Fuel & Year & Geographic plains & City/State & $\begin{array}{c}\text { Particulate } \\
\text { matter }\end{array}$ & $\begin{array}{c}\text { Organic } \\
\text { carbon }(\mathrm{OC})\end{array}$ & $\begin{array}{c}\text { Elemental } \\
\text { carbon }(\mathrm{EC})\end{array}$ & OC/EC & PAHs & Ref. \\
\hline \multirow{21}{*}{$\begin{array}{l}\text { Fuel } \\
\text { wood }\end{array}$} & 2001 & Coastal plain & Mumbai & 1.2 & & - & - & - & [64] \\
\hline & 2002 & & & 1.5 & 0.35 & 0.75 & - & 0.0026 & [65] \\
\hline & 2004 & & & - & 0.59 & - & - & - & [19] \\
\hline & 2005 & & Delhi & - & 3.5 & 1.1 & - & - & [66] \\
\hline & & & India & - & 0.41 & 0.5 & - & - & [67] \\
\hline & 2006 & Indo-Gangetic plain & Punjab & - & 3.76 & & - & - & [68] \\
\hline & & & Delhi & 3.78 & 0.85 & 0.37 & 2.3 & - & [69] \\
\hline & & & Punjab & 4.85 & 0.93 & 0.44 & 2.11 & - & [69] \\
\hline & & & Haryana & 4.11 & 0.78 & 0.42 & 1.86 & - & [69] \\
\hline & & & Uttar Pradesh & 5.99 & 1.32 & 0.31 & 4.26 & - & [69] \\
\hline & & & Bihar & 4.66 & 1.28 & 0.36 & 3.56 & - & [69] \\
\hline & & & Uttarakhand & 3.19 & 0.92 & 0.27 & 3.41 & - & [69] \\
\hline & & & West Bengal & 2.38 & 0.55 & 0.25 & 5.11 & - & [69] \\
\hline & & & Uttarakhand & - & - & - & - & 0.0537 & [70] \\
\hline & & & Haryana & - & - & - & - & 0.0387 & [70] \\
\hline & & & Punjab & - & - & - & - & 0.0393 & [70] \\
\hline & & & Uttar Pradesh & - & - & - & - & 0.0483 & [70] \\
\hline & & & Bihar & - & - & - & - & 0.0453 & [70] \\
\hline & 2013 & Coastal plain & Rajasthan & 1.36 & 0.38 & 0.12 & 3.17 & - & [22] \\
\hline & & & Gujarat & 1.81 & 0.49 & 0.38 & 1.34 & - & [22] \\
\hline & & & Maharashtra & 2.05 & 0.4 & 0.26 & 1.54 & - & [22] \\
\hline \multirow{19}{*}{$\begin{array}{l}\text { Dung } \\
\text { cake }\end{array}$} & & & & - & - & - & - & 0.776 & {$[57]$} \\
\hline & 2001 & & Northern India & 4.9 & - & - & - & & [64] \\
\hline & 2002 & & & 5.04 & 3.47 & 1.32 & - & 0.0043 & [65] \\
\hline & 2005 & Indo-Gangetic plain & Patiala & - & 12.6 & 4.4 & - & - & [66] \\
\hline & & & & & 0.25 & 0.145 & - & - & [67] \\
\hline & 2011 & Indo-Gangetic plain & Delhi & 19.98 & 4.51 & 0.9 & 5.01 & - & [69] \\
\hline & & & Punjab & 16.14 & 4.64 & 0.59 & 7.86 & - & [69] \\
\hline & & & Bihar & 13.84 & 4.14 & 0.28 & 14.79 & - & [69] \\
\hline & & & Uttarakhand & - & - & - & & - & [69] \\
\hline & & & West Bengal & 4.4 & 1.74 & 0.22 & 8.06 & - & [69] \\
\hline & 2012 & Indo-Gangetic plain & Delhi & - & - & - & - & 0.0475 & [70] \\
\hline & & & Uttarakhand & - & - & - & - & 0.0627 & [70] \\
\hline & & & Haryana & - & - & - & - & 0.0666 & [70] \\
\hline & & & Punjab & - & - & - & - & 0.0539 & [70] \\
\hline & & & Uttar Pradesh & - & - & - & & 0.0519 & [70] \\
\hline & & & Bihar & - & - & - & - & 0.0565 & [70] \\
\hline & 2013 & Coastal plain & Rajasthan & 2.82 & 0.74 & 0.15 & 4.93 & - & [22] \\
\hline & & & Gujarat & 8 & 1.24 & 0.14 & 8.86 & - & [22] \\
\hline & & & Maharashtra & 5.26 & 1.58 & 0.14 & 11.29 & - & [22] \\
\hline \multirow{18}{*}{$\begin{array}{l}\text { Crop } \\
\text { residue }\end{array}$} & 2002 & Coastal plain & & 3.88 & 3.88 & 2.51 & - & - & {$[65]$} \\
\hline & 2003 & Indo-Gangetic plain & & - & 1.00 & 5.00 & - & - & [71] \\
\hline & 2005 & Indo-Gangetic plain & Delhi & & 3.90 & 1.30 & & & [66] \\
\hline & & & & - & 2.56 & 0.145 & - & - & [67] \\
\hline & 2006 & Coastal plain & Gujarat & - & - & - & - & 0.00525 & [72] \\
\hline & 2011 & Indo-Gangetic plain & Delhi & 12.1 & 2.1 & 0.57 & 3.68 & - & [69] \\
\hline & & & Punjab & 3.29 & 0.56 & 0.25 & 2.24 & - & [69] \\
\hline & & & Haryana & 3.01 & 0.94 & 0.42 & 2.24 & - & [69] \\
\hline & & & Uttar Pradesh & 8.83 & 2.34 & 0.39 & 6 & - & [69] \\
\hline & & & Bihar & 10.4 & 1.87 & 0.43 & 4.35 & - & [69] \\
\hline & & & West Bengal & 3.26 & 0.97 & 0.18 & 2.26 & - & [69] \\
\hline & & & Punjab & - & - & - & - & 0.04 & [73] \\
\hline & 2012 & Indo-Gangetic plain & Delhi & - & - & - & - & 0.0369 & [70] \\
\hline & & & Haryana & - & - & - & - & 0.0396 & [70] \\
\hline & & & Punjab & - & - & - & - & 0.0374 & [70] \\
\hline & & & Uttar Pradesh & - & - & - & - & 0.0348 & [70] \\
\hline & & & Bihar & - & - & - & - & 0.0305 & [70] \\
\hline & 2013 & Coastal plain & Rajasthan & 1.32 & 0.36 & 0.13 & 2.77 & - & [22] \\
\hline
\end{tabular}



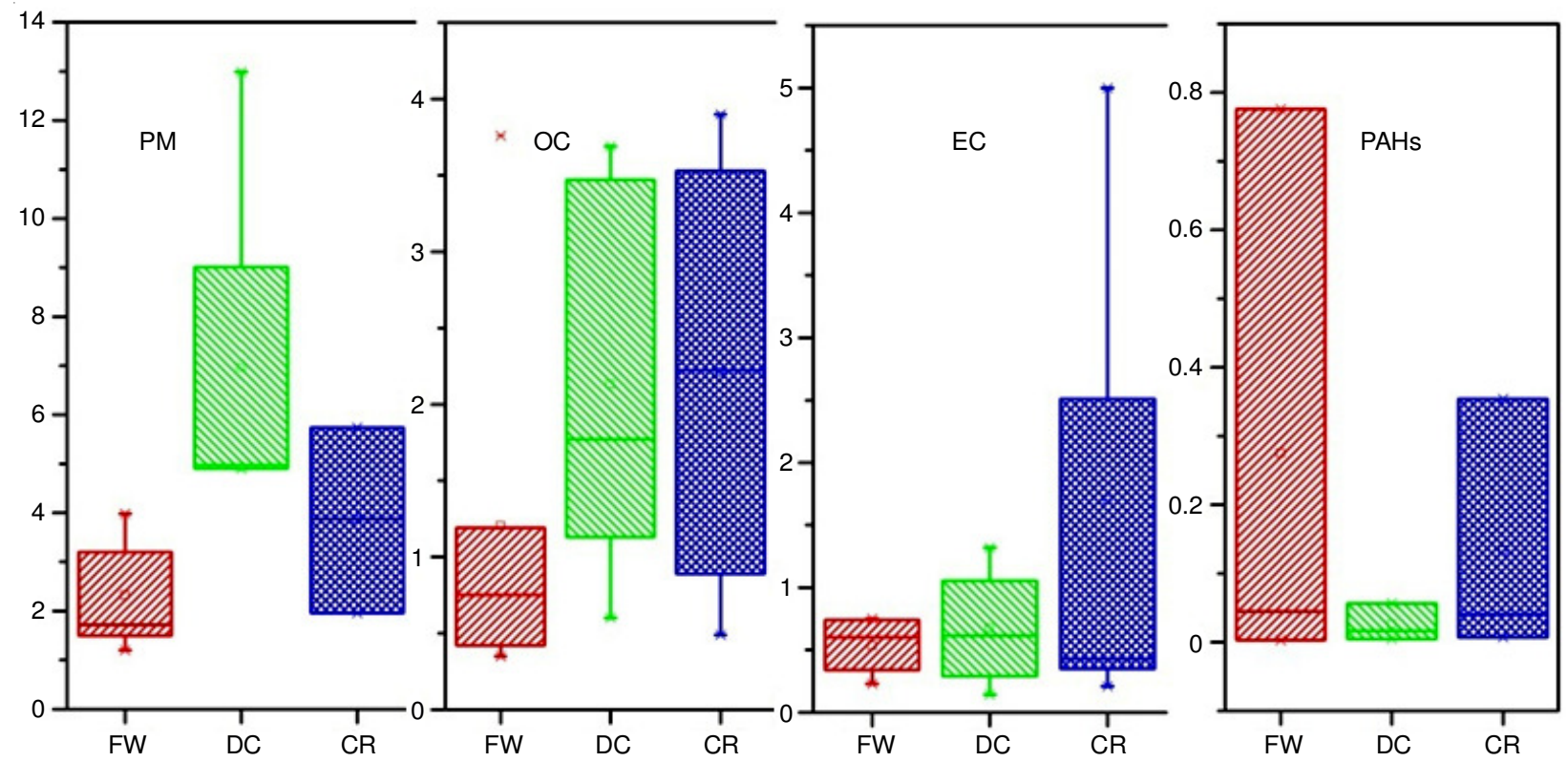

Fig. 3. Comparative emission factors $(\mathrm{g} / \mathrm{kg})$ of particulate matter $(\mathrm{PM})$, organic carbon $(\mathrm{OC})$, elemental carbon (EC) and PAHs reported in previous studies

to fifty-fold higher than dung cakes $(0.17 \mathrm{~g} / \mathrm{kg})$; twenty-fold higher than charcoal $[66,67]$. Most of the reported studies on emission factors of air pollutants from solid fuel burning were conducted with different objectives viz., evaluation of emission budget (EB), address of health effects, comparison between emissions from different solid/liquid fuel combustions and investigations of combustion efficiencies and impacts of associated combustion temperature. Venkatraman et al. [65] conducted a comparative study on mutagenic assessment of aerosols in emissions from biofuel combustion and estimated mutagenicity through emission factors of $\mathrm{PM}_{2.5}$ across various fuels (wood, dung cake, briquette). Dung cakes and briquette shown higher emission factors as well as mutagenicity than wood. Habib et al. [19] reported that the largest black carbon emissions are from fuel wood $(75 \%)$ with lower contributions from dung cakes $(16 \%)$ and crop residue (9\%). Similarly, Sen et al. [22] performed their study on particulate emission from biomass fuels used in the rural area of western India. They reported the average emission factors of dung cakes $(5.37 \pm 3.90 \mathrm{~g} / \mathrm{kg})$ is, 2-3fold higher compared to that of crop residue $(2.15 \pm 1.00$ $\mathrm{g} / \mathrm{kg})$ and fuel wood $(1.69 \pm 0.98 \mathrm{~g} / \mathrm{kg})$ and total emission over coastal plain is much less than Indo-Gangetic plain.

Emission budget: Estimation of total emission for pollutants required, carbon content of the material burned and the carbon budget of the fire. For any fires produced from combustion of a given material, it is assumed that a dry, ashfree carbon content of $45-50 \%$ by mass is available. The total carbon released is usually estimated by adding the measured concentrations of $\mathrm{CO}_{2}, \mathrm{CO}$, hydrocarbons and particulate carbon, when this information is available. Knowledge of emission budgets is important in understanding the impacts of biomass burning on human health, global and climate change. The emission factors of pollutant is also related to the amount of pollutant emitted into the atmosphere that affects directly radiation balance and indirectly the acidification of clouds, rains and fogs. Emission factors are also required in emission inventories and to evaluate the effectiveness of pollution control strategies [63,75-77].

The emission factors were utilized for emission estimation of selected pollutants using summing over the products of emission factors and activities for the emission calculation for the species $\mathbf{i}$ is based on the following equation given by Seiler and Crutzen [78], and Kanokkanjana et al. [79].

$$
\mathrm{E}_{\mathrm{i}}=\mathrm{M} \times \mathrm{EF}_{\mathrm{i}}
$$

where $E_{i}=$ emission flux of pollutant $\mathrm{I}(\mathrm{Gg} / \mathrm{yr}) ; \mathrm{M}=$ amount of dry material burned $(\mathrm{kg}) ; \mathrm{EF}_{\mathrm{i}}=$ emission flux of pollutant I in grams per kilogram of dry matter.

Saud et al. [69] shown in its studies the emission of particulate matter from residential biomass burning over states of Indo-Gangetic plain, India are 21, 16.5, 1.8, 1.4, 0.24 and $0.26 \%$ from Utter Pradesh, Bihar, Punjab, Haryana, Uttarakhand, Delhi, respectively. Total emission from different region of PM, OC, EC, PAHs for different classes of solid biomass fuels have been summarized in Table-4. Fuel wood and dung cakes were available galore in Indo-Gangetic plain, western India and the dependency of the rural population on it as a primary domestic energy source results in huge particulate matter emissions. Similarly, there is extensive usage of agricultural residue and dried animal dung cakes and the associated particulate emissions could have a major impact on the Indian air quality as well as on ambient air quality.

Assessment of adverse health effects due to household air pollution in India: Household air pollution is known as a significant source of severe health risks to exposed populations throughout in worldwide. Exposure to pollutants has also been shown in many recent studies to be associated with several health effects, especially young children and women who cook with solid fuels. A preliminary overview of the literature reflects that there exist a large amount of literature and existing data in the form of published report on IAP $[6,15,50]$. The main diseases according to above literature were respiratory tract 


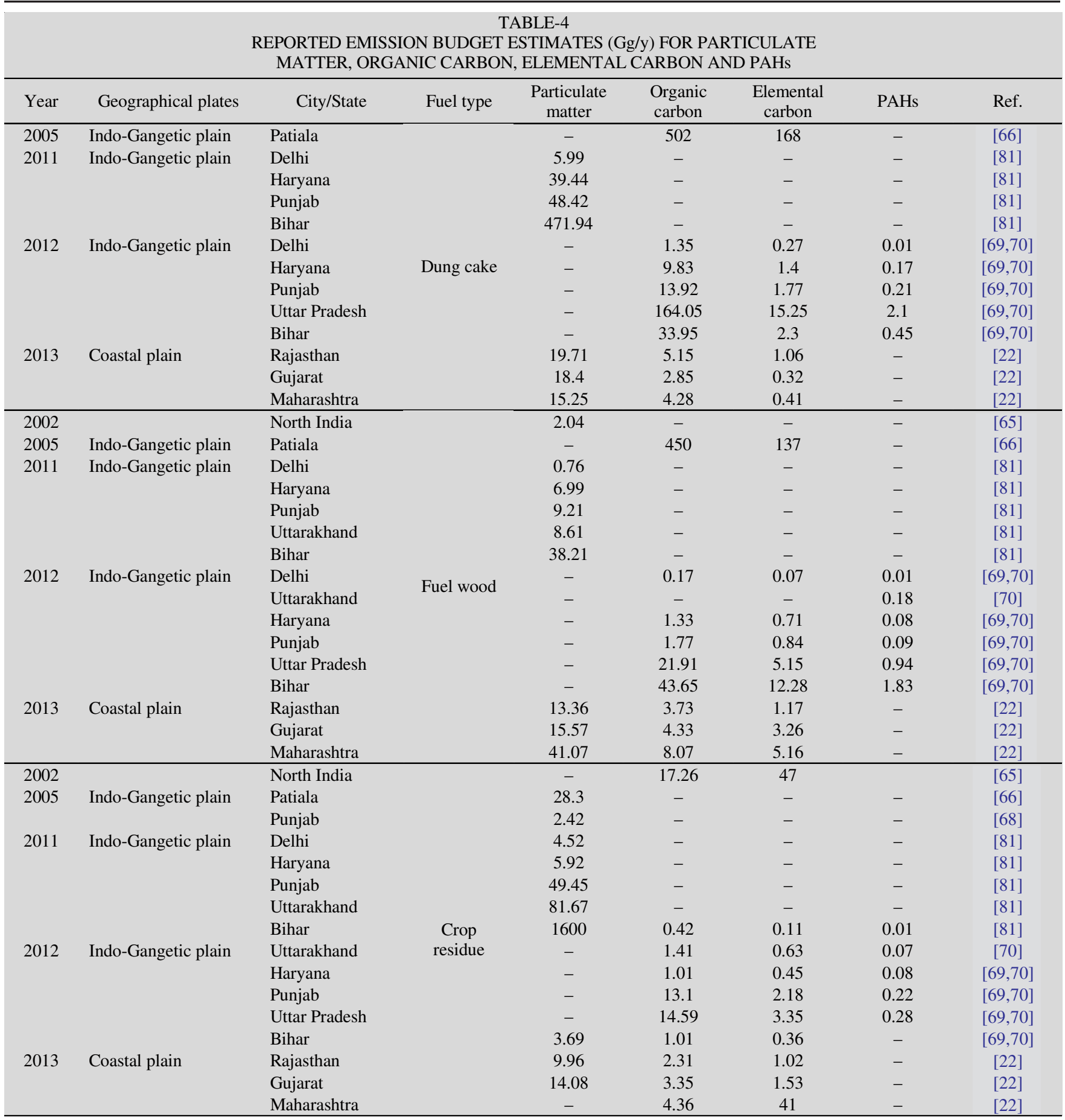

infections, chronic pulmonary diseases, asthma and lungs cancer, etc. The range of risk were found to be 1.2-4.4\% and increased mortality per $10 \mathrm{mg} \mathrm{m}^{-3}$ increase in concentration of RSPM [81]. According to WHO developing countries have major health issues because of profuse use of biomass fuel for the purposes of cooking and heating [82]. An estimated 4.3 million premature deaths from illness to attributable household air pollution caused by the inefficient use of biomass. Among these deaths, $12 \%$ are due to pneumonia, $34 \%$ from stroke, $22 \%$ from chronic obstructive pulmonary disease, $26 \%$ from ischemic heart disease, $6 \%$ from lung cancer [82]. Behera and Balamugesh [7] estimated that the risk of lung cancer was highest for biomass burning exposure with an odds ratio of
5.33 (95\% CI 1.7-16.7). The poorest and susceptible populations in developing countries are mostly exposed in IAP associated to biomass burning $[5,83,84]$. Few studies conducted in India $[83,85,86]$ assessed that household use of coal and kerosene was also associated with an amplified the risks of still births, neonatal deaths, low birth weight. Sapkota et al. [86] compared health risk of coal and wood users; individuals who always used coal as a domestic fuel had lung cancer risk three times higher (i.e. 3.76) than fuel wood users. Bassani et al. [87] compared the mortality rate between girls and boy's child at the age 1-4 year due to exposure of solid biomass burning in separate and non-separate kitchen. Non-separate kitchen was shown higher mortality rate in girl child compa- 
ratively to boy child. Bhat et al. [88] examined respiratory infection in child under the age of 5 years in Udupi district hospital (Bangalore, India) and found that acute lower respiratory tract infections (ALRTI) significantly associated with cooking fuel smoke. They also estimated that among the affected $24.8 \%$ had pneumonia, $45.5 \%$ had severe pneumonia and rest are other sever diseases. Priscilla et al. [58] reported that nasal mucociliary clearance (NMC) time in women (under the age 18-45) significantly prolon-ged in biomass fuel users in comparison to clean fuel users as well as peak respiratory flow rate (PRFR) reduced (319.3 L/min) in biomass users compared to clean fuel users (371.7 L/min).

\section{Conclusion}

Over 50 studies that have been measured IAP levels in houses across all Indian regions, provide clear evidence of acute exposures by using solid fuel as their domestic energy, often manifold higher than recommended WHO Air Quality Guidelines. These studies also indicate that households using cleaner fuels (LPG) show better air quality with respect to the level of different pollutants. The IAP level were in houses using fuel as in following order LPG $<$ kerosene $<$ biomass. Thus, in line with establishes fact that the energy efficiency increase pollution will decrease as we move from solid fuels to liquid like kerosene and gaseous fuel. Based on the results of review, dung cakes is of particular interest as this is one of the most common fuels used across the country. When compared with LPG, it generates approximately four to five times higher gaseous pollutants as well as particulate matter $\left(\mathrm{PM}_{10}\right.$ as well as $\left.\mathrm{PM}_{2.5}\right)$. Considering the insufficient supply of cleaner fuels (LPG) to rural areas of India, the use of fuel wood, dung cakes and crop residue for the cooking purpose would continue as the most common fuel.

In India, most of the studies in residential biomass burning were conducted in Indo-Gangetic plain in the last decade. Around $82-85 \%$ of studies were focused on concentration level of particulate matter during cooking practices and associated health effects compared to indoor levels (3-5\%) and emission factors as well as emission budgets of various hazards pollutants. Most of people spend $>90 \%$ of their time indoors in both urban and rural area. Occurrences of higher indoor particulate matter associated toxic component address the increasing patients of long and short-term adverse health effects. Results of these review from reported studies in Indian region has shown multi-fold higher concentration of indoor particulate matter fractions including $\mathrm{PM}_{10}$ compared to those found outdoors. Few studies address the chemical characterization of indoor particulate matter fractions along with associated health effects. Some of reported studies on physico-chemical characterization of emissions resulting from household biomass burning emissions have shown associated impacts on Indian air quality. Based on findings of this review, the emission factors and emission budgets of pollutants (particulate matter, carbonaceous matter) and health risk assessment studies are strongly recommended in future to develop strong and efficient control policy on household air pollution in India.

\section{ACKNOWLEDGEMENTS}

This study is supported by DST project proposal (EMR/ 2015/000928) and partially supported by DST FIST program (SR/FST/CSI-259/2014 (c)) and UGC-SAP-DRS-II program
(F-540/7/DRS-II/2016 (SAP-I)). One of the author (MV) is grateful to Pt. Ravishankar Shukla University for providing university fellowship (No./1732/10/Sch./2017) and laboratory facilities. Another authors (MV and SP) are also thankful to CSIR-National Environment Engineering Research Institute for providing initial plagiarism report of the manuscript by registered iThenticate software under KRC no: CSIR NEERI/ KRC/2017/JAN/KZL/1.

\section{REFERENCES}

1. WRI, 2007-08 World Resources: A Guide to the Global Environment, World Resources Institute, Oxford University Press (2008).

2. I. Colbeck, Z.A. Nasir and Z. Ali, Indoor Air, 20, 40 (2010); https://doi.org/10.1111/j.1600-0668.2009.00624.x.

3. N. Dubey and S. Pervez, Aerosol Air Qual. Res., 8, 54 (2008); https://doi.org/10.4209/aaqr.2007.07.0033.

4. R. Goyal and P. Kumar, Air Qual. Atmos. Health, 6, 747 (2013); https://doi.org/10.1007/s11869-013-0212-0.

5. V. Mishra, Environ. Health Perspect., 111, 71 (2003).

6. K. Balakrishnan, S. Sambandam, P. Ramaswamy, S. Mehta and K.R. Smith, J. Expos. Sci. Environ. Epidemiol., 14, S14 (2004); https://doi.org/10.1038/sj.jea.7500354.

7. D. Behera and T. Balamugesh, J. Assoc. Phys. India, 53, 190 (2005).

8. K.R. Smith, Ann. Rev. Energy Environ., 18, 529 (1993).

9. C. Chengappa, R. Edwards, R. Bajpai, K.N. Shields and K.R. Smith, Energy Sustain. Dev., 11, 33 (2007); https://doi.org/10.1016/S0973-0826(08)60398-1.

10. J.J. Zhang and L. Morawska, Chemosphere, 49, 1059 (2002); https://doi.org/10.1016/S0045-6535(02)00240-0.

11. WHO, The World Health Report 2012-Global Health Observatory (GHO) Data (2012).

12. WHO, The World Health Report 2008-Primary Health Care: Now More than Ever (2008).

13. K.R. Smith, Proc. Natl. Acad. Sci. USA, 97, 13286 (2002); https://doi.org/10.1073/pnas.97.24.13286.

14. N. Englert, Toxicol. Lett., 149, 235 (2004); https://doi.org/10.1016/j.toxlet.2003.12.035.

15. K. Balakrishnan, S. Sankar, J. Parikh, R. Padmavathi, K. Srividya, V. Venugopal, S. Prasad and V.L. Pandey, Environ. Health Perspect., 110, 1069 (2002).

16. J. Zhang and K.R. Smith, Environ. Health Perspect., 115, 848 (2007).

17. O. Gustafsson, N.M. Krus, Z. Zencak, R.J. Sheesley, L. Granat, E. Engstrom, P.S. Praveen, P.S.P. Rao, C. Leck and H. Rodhe, Science, 323, 495 (2009); https://doi.org/10.1126/science.1164857.

18. S. Saksena, P.B. Singh, R.K. Prasad, R. Prasad, P. Malhotra, V. Joshi and R.S. Patil, J. Expos. Sci. Environ. Epidemiol., 13, 219 (2003); https://doi.org/10.1038/sj.jea.7500273.

19. G. Habib, C. Venkataraman, M. Shrivastava, R. Banerjee, J.W. Stehr and R.R. Dickerson, Global Biogeochem. Cycles, 18, (2004); https://doi.org/10.1029/2003GB002157.

20. R. Gadi, D.P. Singh, T. Saud, T.K. Mandal and M. Saxena, Human Ecol. Risk Assess.: An Int. J., 18, 871 (2012); https://doi.org/10.1080/10807039.2012.688714.

21. K. Balakrishnan, S. Ghosh, B. Ganguli, S. Sambandam, N. Bruce, D.F. Barnes and K.R. Smith, Environ. Health, 12, 77 (2013); https://doi.org/10.1186/1476-069X-12-77.

22. A. Sen, T.K. Mandal, S.K. Sharma, M. Saxena, N.C. Gupta, R. Gautam, A. Gupta, T. Gill, S. Rani, T. Saud, D.P. Singh and R. Gadi, Atmos. Environ., 99, 411 (2014); https://doi.org/10.1016/j.atmosenv.2014.09.012.

23. S. Dewangan, Ph.D. Thesis, Study on Emission Estimation of Selected Carbonaceous Pollutants During Ritual Based Stuff Burning Activities, Pt. Ravishankar Shukla University, Raipur, India (2014).

24. P. Singh, R. Saini and A. Taneja, Atmos. Pollut. Res., 5, 352 (2014); https://doi.org/10.5094/APR.2014.041.

25. S. Pervez, J. Mathew and R. Sharma, J. Sci. Ind. Res. (India), 64, 454 (2005).

26. K. Dutta, K.N. Shields, R. Edwards and K.R. Smith, Energy Sust. Dev., 11, 19 (2007); https://doi.org/10.1016/S0973-0826(08)60397-X. 
27. D. Massey, J. Masih, A. Kulshrestha, M. Habil and A. Taneja, Build. Environ., 44, 2037 (2009); https://doi.org/10.1016/j.buildenv.2009.02.010.

28. R.R. Krishna, Curr. Sci., 102, 440 (2012).

29. N.L. Lam, K.R. Smith, A. Gauthier and M.N. Bates, J. Toxicol. Environ. Health, Part B, 15, 396 (2012); https://doi.org/10.1080/10937404.2012.710134.

30. T. Lahiri and S. Chowdhury, Final Report, Impact of Indoor Air Pollution from Biomass Fuel Burning on Reproductive Health and Neurobehavioral Symptoms of Premenopausal Women in Rural India, Nature Environment and Wildlife Society (NEWS), Kolkata, India (2009).

31. P. Rajput, M. Sarin, D. Sharma and D. Singh, Tellus B: Chem. Phys. Meterol., 66, Article 21026 (2014); https://doi.org/10.3402/tellusb.v66.21026.

32. R. Goyal and M. Khare, Atmos. Environ., 43, 6026 (2009); https://doi.org/10.1016/j.atmosenv.2009.08.031

33. A. Kulshrestha, D.S. Bisht, J. Masih, D. Massey, S. Tiwari and A. Taneja, J. Atmos. Chem., 62, 121 (2009); https://doi.org/10.1007/s10874-010-9143-4.]

34. G. Balakrishna and S. Pervez, Aerosol Air Qual. Res., 9, 359 (2009); https://doi.org/10.4209/aaqr.2008.12.0065.

35. D.S. Thambavani and M.V. Vathana, J. Res. Biol., 2, 1 (2012).

36. D.D. Massey, A. Kulsrestha and A. Taneja, 2nd International Conference on Environmental and Computer Science (ICECS '09), IEEE, Dubai, UAE, 28-30 December (2009). https://doi.org/10.1109/ICECS.2009.45.

37. M. Sahu, J. Peipert, V. Singhal, G.N. Yadama and P. Biswas, Environ. Sci. Technol., 45, 2428 (2011); https://doi.org/10.1021/es1029415.

38. U. Mukkannawar, R. Kumar and A. Ojha, Int. J. Curr. Microbiol. Appl. Sci., 3, 683 (2014)

39. P. Kulshreshtha and M. Khare, Atmos. Pollut. Res., 2, 337 (2011); https://doi.org/10.5094/APR.2011.038.

40. N. Verma and A. Taneja, Indian J. Environ. Prot., 31, 627 (2011).

41. R. Mukhopadhyay, S. Sambandam, A. Pillarisetti, K. Mukhopadhyay, D. Jack, K. Balakrishnan, M. Vaswani, M.N. Bates, P.L. Kinney, N. Arora and K.R. Smith, Global Health Action, 5:1, 19016 (2012); https://doi.org/10.3402/gha.v5i0.19016.

42. S. Pervez, N. Dubey, J.G. Watson, J. Chow and Y. Pervez, Aerosol Air Qual. Res., 12, 49 (2012); https://doi.org/10.4209/aaqr.2011.08.0124.

43. P.G. Satsangi, S. Yadav, A.S. Pipal and N. Kumbhar, Atmos. Environ., 92, 384 (2014) https://doi.org/10.1016/j.atmosenv.2014.04.047.

44. V.S. Chithra and S.M.S. Nagendra, Atmos. Environ., 77, 579 (2013); https://doi.org/10.1016/j.atmosenv.2013.05.044.

45. A. Kulshrestha, D. Massey, J. Masih and A. Taneja, Aerosol Air Qual. Res., 14, 1738 (2014); http://dx.doi.org/10.4209/aaqr.2013.05.0147.

46. R. Roy, R. Jan, S. Yadav, M.H. Vasave and P.G. Satsangi, Air Qual. Atmos. Health, 9, 669 (2015); https://doi.org/10.1007/s11869-015-0376-X

47. R. Tiwari, eds.: P. Sharma and S. Rajput, Levels of Air Pollution in Lucknow, Uttar Pradesh, In: Sustainable Smart Cities in India, The Urban Book Series, Springer, Cham (2017).

48. G. Balakrishna, S. Pervez and D.S. Bisht, Atmos. Chem. Phys. Discuss., 10, 26411 (2010); https://doi.org/10.5194/acpd-10-26411-2010.

49. J. Masih, R. Singhvi, K. Kumar, V.K. Jain and A. Taneja, Aerosol Air Qual. Res., 12, 515 (2012); https://doi.org/10.4209/aaqr.2011.11.0192.

50. M.A. Desai, S. Mehta and K.R. Smith, Indoor Smoke from Solid Fuels: Assessing the Environmental Burden of Disease at National and Local Levels, World Health Organization: Geneva (2004).

51. D. Chakraborty, N.K. Mondal and J.K. Datta, Int. J. Sustain. Built Environ., 3, 262 (2014); https://doi.org/10.1016/i.ijsbe.2014.11.002.

52. J. Parikh, K. Balakrishnan, V. Laxmi and H. Biswas, Energy, 26, 949 (2001); https://doi.org/10.1016/S0360-5442(01)00043-3.
53. R. Abalak, B. Nigel, J.P. Mccracken, K.R. Smith and T. de Gallardo, Environ. Sci. Technol., 35, 2650 (2001); https://doi.org/10.1021/es001940m.

54. A.L. Singh and S. Jamal, J. Environ. Res. Manage., 3, 001 (2012).

55. A.L. Singh and S. Jamal, J. Geograp. Reg. Plan., 1, 1 (2012).

56. M.K. Sidhu, K. Ravindra, S. Mor and S. John, Sci. Total Environ., 586, 419 (2017); https://doi.org/10.1016/j.scitotenv.2017.01.051.

57. Aakanksha, R. Katiyar and S.K. Rastogi, Curr. World Environ., 9, 525 (2014); http://dx.doi.org/10.12944/CWE.9.2.37.

58. J. Priscilla, R. Padmavathi, S. Ghosh, P. Paul, S. Ramadoss, K. Balakrishnan, V. Thanasekaraan and A.S. Subhashini, Lung India, 28, 30 (2011); https://doi.org/10.4103/0970-2113.76298.

59. K.R. Smith, Biofuels, Air Pollution and Health A Global Review, Springer (1987).

60. J.S. Reid, R. Koppmann, T.F. Eck and D.P. Eleuterio, Atmos. Chem. Phys., 5, 799 (2005) https://doi.org/10.5194/acp-5-799-2005.

61. T.C. Bond and R.W. Bergstrom, Aerosol Sci. Technol., 40, 27 (2006); https://doi.org/10.1080/02786820500421521.

62. M.O. Andreae and P. Merlet, Global Biogeochem. Cycles, 15, 955 (2001); https://doi.org/10.1029/2000GB001382.

63. S.K. Akagi, R.J. Yokelson, C. Wiedinmyer, M.J. Alvarado, J.S. Reid, T. Karl, J.D. Crounse and P.O. Wennberg, Atmos. Chem. Phys., 11, 4039 (2011); https://doi.org/10.5194/acp-11-4039-2011.

64. C. Venkataraman and G.U.M. Rao, Environ. Sci. Technol., 35, 2100 (2001); https://doi.org/10.1021/es001603d.

65. M.S. Reddy and C. Venkataraman, Atmos. Environ., 36, 699 (2002); https://doi.org/10.1016/S1352-2310(01)00464-2.

66. D.C. Parashar, R. Gadi, T.K. Mandal and A.P. Mitra, Atmos. Environ., 39, 7861 (2005); https://doi.org/10.1016/j.atmosenv.2005.08.034.

67. C. Venkataraman, G. Habib, A. Eiguren-Fernandez, A.H. Miguel and S.K. Friedlander, Science, 307, 1454 (2005); https://doi.org/10.1126/science.1104359.

68. K.V.S. Badarinath, T.R. Kiran Chand and V. Krishna Prasad, Curr. Sci., 91, 1085 (2006).

69. T. Saud, R. Gautam, T.K. Mandal, R. Gadi, D.P. Singh, S.K. Sharma, M. Dahiya and M. Saxena, Atmos. Environ., 61, 212 (2012); https://doi.org/10.1016/j.atmosenv.2012.07.030.

70. D.P. Singh, R. Gadi, T.K. Mandal, T. Saud, M. Saxena and S.K. Sharma, Atmos. Environ., 68, 120 (2013); https://doi.org/10.1016/j.atmosenv.2012.11.042.

71. D.G. Streets, K.F. Yarber, J.H. Woo and G.R. Carmichael, Global Biogeochem. Cycles, 17, 1099 (2003); https://doi.org/10.1029/2003GB002040.

72. S.N. Sinha, P.K. Kulkarni, S.H. Shah, N.M. Desai, G.M. Patel, M.M. Mansuri and H.N. Saiyed, Sci. Total Environ., 357, 280 (2006); https://doi.org/10.1016/j.scitotenv.2005.08.011.

73. P. Rajput, M.M. Sarin, R. Rengarajan and D. Singh, Atmos. Environ., 45, 6732 (2011); https://doi.org/10.1016/i.atmosenv.2011.08.018.

74. S. Pervez, R. Chakrabarty, S. Dewangan, J.W. Watson, J.C. Chow, J.L. Matawle and Y. Pervez, Aerosol Air Qual. Res., 15, 72 (2015); https://doi.org/10.4209/aaqr.2014.01.0022.

75. R. Dhammapala, C. Claiborn, J. Jimenez, J. Corkill, B. Gullett, C. Simpson and M. Paulsen, Atmos. Environ., 41, 2660 (2007); https://doi.org/10.1016/j.atmosenv.2006.11.023.

76. R. Dhammapala, C. Claiborn, C. Simpson and J. Jimenez, Atmos. Environ., 41, 1512 (2007); https://doi.org/10.1016/j.atmosenv.2006.10.008.

77. R.J. Yokelson, I.R. Burling, S.P. Urbanski, E.L. Atlas, K. Adachi, P.R. Buseck, C. Wiedinmyer, S.K. Akagi, D.W. Toohey and C.E. Wold, Atmos. Chem. Phys., 11, 6787 (2011); https://doi.org/10.5194/acp-11-6787-2011.

78. W. Seiler and P.J. Crutzen, Climatic Change, 2, 207 (1980); https://doi.org/10.1007/BF00137988. 
79. K. Kanokkanjana, P. Cheewaphongphan and S. Garivait, Black Carbon Emission from Paddy Field Open Burning in Thailand, IPCBEE Proc., vol. 6, pp. 88-92 (2011).

80. T. Sauda, T.K. Mandal, R. Gadi, D.P. Singh, S.K. Sharma, M. Saxena and A. Mukherjee, Atmos. Environ., 45, 5913 (2011); https://doi.org/10.1016/j.atmosenv.2011.06.031.

81. D. Prasad and S. Sanyal, Space Cult. India, 4, 51 (2016); https://doi.org/10.20896/saci.v4i1.164.

82. WHO, Household Air Pollution and Health (2014).

83. M.B. Epstein, M.N. Bates, N.K. Arora, K. Balakrishnan, D.W. Jack and K.R. Smith, Int. J. Hyg. Environ. Health, 216, 523 (2013); https://doi.org/10.1016/j.ijheh.2012.12.006.

84. S. Agrawal and S. Yamamoto, Indoor Air, 25, 341 (2015); https://doi.org/10.1111/ina.12144.
85. P.V.M. Lakshmi, N.K. Virdi, A. Sharma, J.P. Tripathy, K.R. Smith, M.N. Bates and R. Kumar, Environ. Res., 121, 17 (2013); https://doi.org/10.1016/j.envres.2012.12.004.

86. A. Sapkota, V. Gajalakshmi, D.H. Jetly, S. Roychowdhury, R.P. Dikshit, P. Brennan, M. Hashibe and P. Boffetta, Int. J. Epidemiol., 37, 321 (2008); https://doi.org/10.1093/ije/dym261.

87. D.G. Bassani, P. Jha, N. Dhingra and R. Kumar, BMC Public Health, 10, 491 (2010); https://doi.org/10.1186/1471-2458-10-491.

88. Y. Ramesh Bhat, N. Manjunath, D. Sanjay and Y. Dhanya, Paediat. Int. Child Health, 32, 132 (2012); https://doi.org/10.1179/2046905512Y.0000000027. 